\title{
Spatial pattern of heavy metals accumulation risk in urban soils of Beijing and its influencing factors
}

\author{
Rui Liu, Meie Wang, Weiping Chen*, Chi Peng \\ State Key Laboratory for Urban and Regional Ecology, Research Center for Eco-Environmental Sciences, Chinese Academy of Sciences, Beijing 100085, China
}

\section{A R T I C L E I N F O}

\section{Article history:}

Received 17 June 2015

Received in revised form

23 November 2015

Accepted 24 November 2015

Available online 21 December 2015

\section{Keywords:}

Beijing

Urbanization

Soil pollution

Regression tree

Heterogeneity

\begin{abstract}
A B S T R A C T
Accumulations of heavy metals in urban soils are highly spatial heterogeneity and affected by multiple factors including soil properties, land use and pattern, population and climatic conditions. We studied accumulation risks of $\mathrm{Cd}, \mathrm{Cu}, \mathrm{Pb}$ and $\mathrm{Zn}$ in unban soils of Beijing and their influencing based on the regression tree analysis and a GIS-based overlay model. Result shows that Zinc causes the most extensive soil pollution and $\mathrm{Cu}$ result in the most acute soil pollution. The soil's organic carbon content and CEC and population growth are the most significant factors affecting heavy metal accumulation. Other influence factors in land use pattern, urban landscape, and wind speed also contributed, but less pronounced. The soils in areas with higher degree of urbanization and surrounded by intense vehicular traffics have higher accumulation risk of $\mathrm{Cd}, \mathrm{Cu}, \mathrm{Pb}$, and $\mathrm{Zn}$.
\end{abstract}

(c) 2015 Elsevier Ltd. All rights reserved.

\section{Introduction}

Urbanization processes not only changed inherent properties of the affected soils, such as their $\mathrm{pH}$, texture, cation exchange capacity, and bulk density but also inadvertently caused harmful substances such as heavy metals to deposit in the soils (Vega et al., 2004; WRB, 2006; Obrador et al., 2007). The pollutant accumulations often led to environmental ills (Pouyat and McDonnell, 1991; Bermea et al., 2009; Chabukdhara and Nema, 2013). In China, the $\mathrm{Cd}, \mathrm{Cu}, \mathrm{Pb}$ and $\mathrm{Zn}$ concentrations of urban soils were frequently found to exceed the baseline and the levels were rising (Wei and Yang, 2010; Wang et al., 2012a,b).

Besides, urban development altered the natural landscapes and microclimatic features, created man-made topographies, and concentrated the human populations and activities that in turn would influence the pollutant deposition processes (Lin et al., 2002; Xia et al., 2011). Industrial establishments, transportation networks, residential communities, and other support systems were integrated across the urban horizons to make depositions of heavy metal in urban soils a complicated undertaking (Legret and Pagotto, 2006; Han et al., 2006; Mmolowa et al., 2011). Statistical methods, such as the correlation and regression analyses, were utilized to

\footnotetext{
* Corresponding author

E-mail address: wpchen@rcees.ac.cn (W. Chen).
}

empirically link heavy metals deposited in the urban soils to potential causative urban factors (Zeng et al., 2011; Palumbo et al., 2000). The methods had not been entirely successful as the outcomes were simplistic and failed to consider the complex spatial and interactive nature of the causative factors. For a complicated system such as the urban metropolises, the classification and regression tree (CART) analysis would be an efficient approach to deduce relationships between heavy metal depositions and causative factors and to distinguish influences of the factors (Kheir et al., 2014; Greve et al., 2012). The CART was capable to search for the non-additive and non-linear relationships, and to uncover the hidden structures in complex data matrices (Breiman, 2001; Henderson et al., 2005; Razi and Athappilly, 2005).

The geo-statistical tool Kriging would convert the soil pollutant levels measured at point locations into spatial distribution of pollution across the urban landscape. The outcomes, however, tended to gloss over the distinctive local highs and lows because of the smoothed extrapolation technique (Journel et al., 2000) thus failed to preserve the highly variable nature and skewed pollutant distributions of the actual urban environment and reduced the accuracy of assessments (Goovaerts, 2000), especially for the highly heterogeneous urban environment. A more robust approach to evaluate the spatial variation of heavy metal contaminations in urban area would be the GIS-based model that linked and integrated the spatial distribution of heavy metals with the spatially referenced data of causative factors (Desmet and Govers, 1996). 
We hypothesized that the soil, land use, demographic, and climatic factors influenced the spatial distribution of heavy metals in urban soils. Used the CART analysis and a GIS-based model to illustrate how causative factors including soil properties, urban land use, demographics, and microclimatic conditions would affect the distribution of $\mathrm{Cd}, \mathrm{Cu} \mathrm{Pb}$ and $\mathrm{Zn}$ in the urban soils throughout Beijing.

\section{Materials and methods}

\subsection{Study area}

The urban built-up areas of Beijing (Fig. 1), which encompassed areas inside of the 5th ring road of Beijing and included the Dongcheng and Xicheng Districts and parts of the Haidian, Chaoyang, Fengtai, and Shijingshan Districts were the study template. The area belonged to warm temperate semi-humid continental monsoon climate and the prevalent winds were northwest and south in directions. The cinnamon and fluvo-aquic were the dominant soils with parent materials consisted of weathering rocks and loose quaternary sediment. The city in recent decades experienced drastic and rapid urban renewal and developments. From 1949 to 2012, the population increased from 1.8 to 20.7 million, while the built-up areas increased from 109 to $670 \mathrm{~km}^{2}$.

\subsection{Soil sampling}

To ensure a uniform distribution of sampling sites, the study area was divided by $1 \mathrm{~km} \times 1 \mathrm{~km}$ sized grids on Google Earth, and then sample site was selected from each grid based on the land use and topographic conditions (some grids were unavailable for sampling). Finally, 232 sample sites were selected (Fig. 1). Surface soil (0-20 cm depth) samples were collected. Crumbled and free of roots and other organic debris, the specimens were then air-dried and crushed passed through a sieve of $2 \mathrm{~mm} \times 2 \mathrm{~mm}$ openings. Each specimen was then subdivided with three quarter of the material preserved for analyzing $\mathrm{pH}$ and soil particle size, and the remaining one quarter of the material further ground to pass a sieve of $0.15 \mathrm{~mm} \times 0.15 \mathrm{~mm}$ openings to be used in analysis of soil organic carbon and cation exchange capacity. In addition, $100 \mathrm{~cm}^{3}$ intact soil cores were obtained in metal cylinders made from $5 \mathrm{~cm}$ ID straight brass tubing and were kept at the field moisture content in cold storage. Later, they were used to determine the field capacity and bulk density of the soils.

\subsection{Chemical analysis}

The soil $\mathrm{pH}$ was determined in 1:2.5 weigh vs. volume aqueous soil suspension via glass electrodes potentiometry. The soil particle size distribution was determined by a laser particle size analyzer and the outcomes reported according to the United States Department of Agriculture (USDA) soil classification scheme in which the clay content (CLAY) denoted the percentage of particles with sizes less than $0.002 \mathrm{~mm}$. The soil organic carbon content was measured using a $\mathrm{C}-\mathrm{N}-\mathrm{S}$ elemental analyzer, provided the soil aliquot was pretreated with $1 \mathrm{~mol} / \mathrm{L} \mathrm{HCL}$ to remove the inorganic

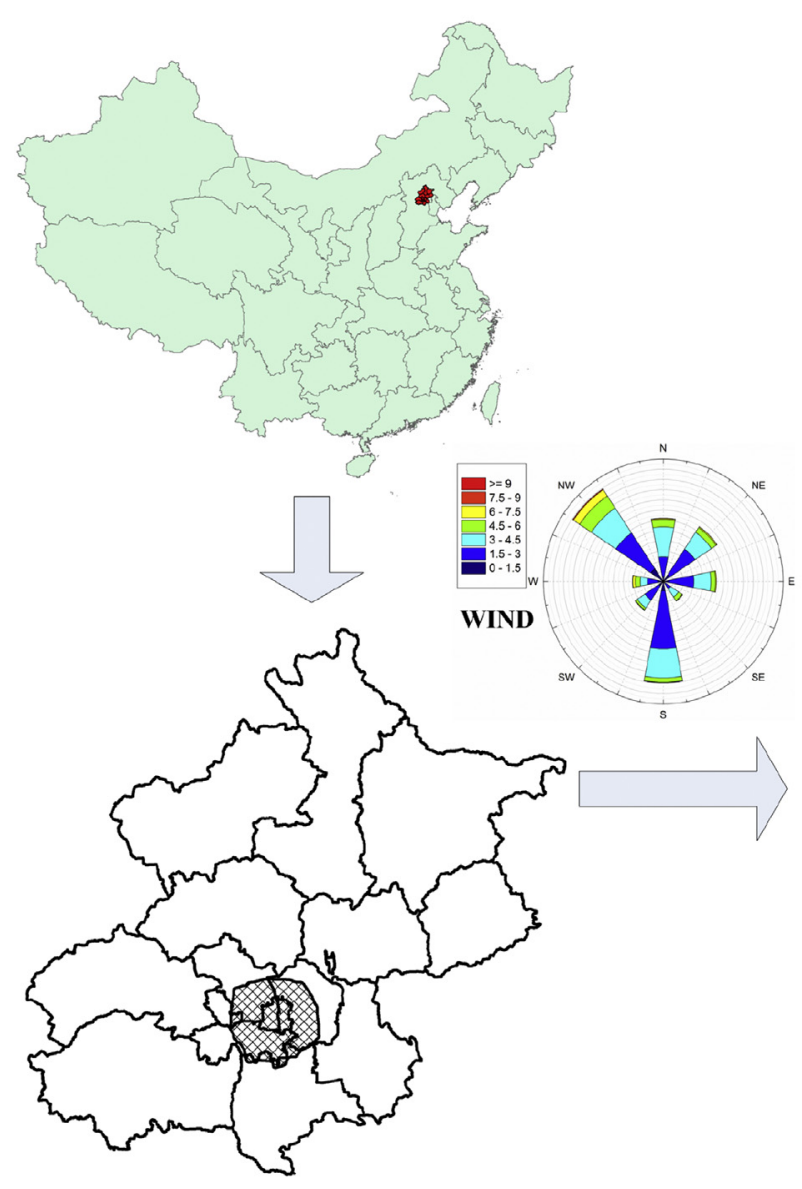

$\Lambda$

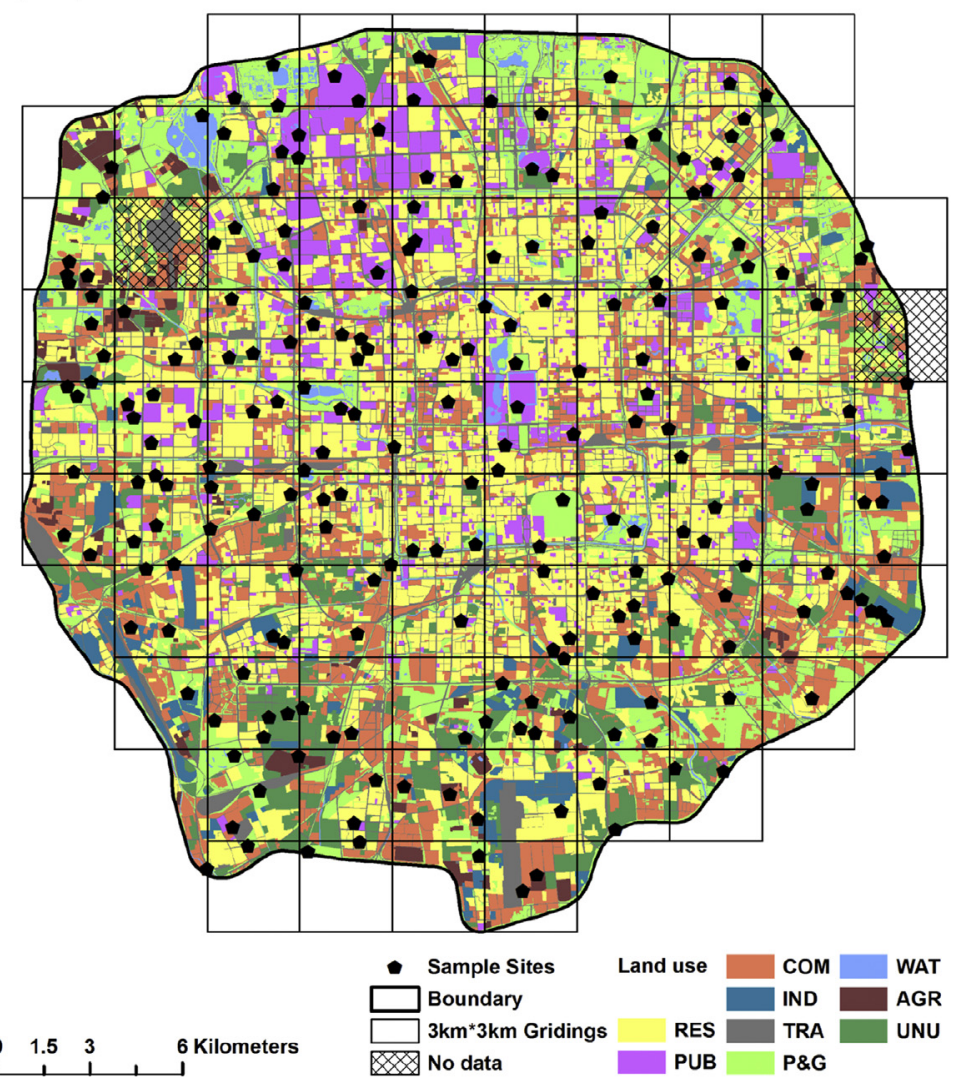

Fig. 1. Study area and soil sampling sites. 
carbon. The soil's cation exchange capacity (CEC) was determined by the sodium acetate extraction method according to the U. S. Environmental Protection Agency (EPA) Method 9081.

The $\mathrm{Cd}, \mathrm{Cu}, \mathrm{Pb}$, and $\mathrm{Zn}$ contents of soils were obtained by first digesting a $0.25 \mathrm{~g}$ soil aliquot (ground to pass a sieve of $0.1 \mathrm{~mm}$ openings) in $10 \mathrm{ml} \mathrm{HCL}$ overnight, then heated to reduce down to $3 \mathrm{ml}$ and then continued the heating with $5 \mathrm{ml} \mathrm{HNO}_{3}, 5 \mathrm{ml} \mathrm{HF}$, and $3 \mathrm{ml} \mathrm{HClO}_{4}$ until $3 \mathrm{ml}$ remained. The final suspension would be further digested (repeated if necessary) in $2 \mathrm{ml} \mathrm{HNO}_{3}, 2 \mathrm{ml}$ of HF, and $1 \mathrm{ml} \mathrm{HClO}_{4}$ until the solution turned clear. The digested extracts were diluted by ultrapure water at 1 to 50 for ICP-OES analysis of $\mathrm{Cu}$ and $\mathrm{Zn}$, and at $1-250 \mathrm{ml}$ for ICP-MS spectrometry analysis of $\mathrm{Cd}$ and $\mathrm{Pb}$.

\subsection{Quality assurance and quality control}

The national registered standard reference materials, GSS-13 (Geochemical Standard soil) was included in chemical analyses. The mean recoveries were $83 \%$ for $\mathrm{Cd}, 71 \%$ for $\mathrm{Cu}, 91 \%$ for $\mathrm{Pb}$ and $98 \%$ for $\mathrm{Zn}$. Duplicates were analyzed on $10 \%$ of the soil samples and the standard deviations were within $\pm 5 \%$ of the mean. Reagent blanks were included with each batch of samples analyzed.

\subsection{Grid transformation}

To spatially synchronize the data on soil properties with urban geographical date for statistical analyses, the 231 soil sampling grids were consolidated and transformed into $813 \mathrm{~km} \times 3 \mathrm{~km}$ cells (Fig. 1). The soil properties of a cell were represented by the mathematic averages of those within a cell. Accordingly, the population, land use, and meteorological data were also spatially transformed into 81 cells.

\subsection{Data collection and spatialization}

The land uses were delineated from the high-resolution remote sense images of IKONOS that were collected on July 29, 2012 and were classified into 9 types, including agricultural (AGR), commercial (COM), industrial (IND), parks and greenbelt ( $P \& G$ ), public (PUB, include land used by public facilities, such as school, hospital, stadium and research institution), residential (RES), traffic (TRA, include land used by different grade roads, railways and public transportation depots), water body (WAT, include artificial or natural lakes and rivers), and unused (UNU, include land that was under construction and those were currently idle). The proportions of land uses in each cell were then calculated. The urban landscapes were described by landscape metrics, which were computed by Fragstats vision 4.2., after land use vector data were converted into raster data and separated by the $3 \mathrm{~km} \times 3 \mathrm{~km}$ cells.

The population data were based on statistics of the 2000 and 2010 national census that included populations of the districts. The population of each $3 \mathrm{~km} \times 3 \mathrm{~km}$ cell was visualized and calculated using ArcGIS 9.3 spatial analysis tools and the 2000 to 2010 average annual population growth rates were calculated.

The Urban Ecosystem Research Station of Beijing provided the meteorological data including wind direction and wind speed. Data were recorded at hour interval, from 2010 to 2013. To be compatible with other matrices, the 81 cell were categorized into 8 classes and assigned a numerical value based on their location in the study region, namely, north $=1$, north-east $=2$, east $=3$, south-east $=4$, south $=5$, south-west $=6$, west $=7$, and north-west $=8$. The annual mean speed of each cell was then calculated.

\subsection{Calculation of geoaccumulation index ( $\left.I_{g e o}\right)$}

A modified Geoaccumulation index ( $\left.I_{\text {geo }}\right)$ was used to reflect the influences made by human activities on soils heavy metals contamination. The equation is given as:

$I_{\text {geo }}=\log _{2}\left(C_{n} / 1.5 B_{n}\right)$

where $C_{n}$ was the concentration of the examined element in the examined bottom sediment, $B_{n}$ was the geochemical background of a given element in mudstone, in this study, the Beijing soil background values were used (Table 2). 1.5 was a modified index, which would multiply the concentration of geochemical background in order to allow content fluctuations of a given substance in the urban environment as well as very small anthropogenic influences. The geoaccumulation index of $\mathrm{Cd}, \mathrm{Cu}, \mathrm{Pb}$ and $\mathrm{Zn}$ were calculated separately.

\subsection{Regression tree analysis}

Two types of regression tree analysis were conducted to identify the influences of the 40 selected factors (independent variable) on soil heavy metal pollution (dependent variables). In the univariate regression tree (URT), individual concentration of $\mathrm{Cd}, \mathrm{Cu}, \mathrm{Pb}$, and $\mathrm{Zn}$ in urban soils was set as dependent variable, while in the multivariate regression tree (MRT), the four metal concentrations in urban soils were set as one dependent variable (Table 1). The regression trees were developed based on those data generated for the 81 spatial cells. Trees were constructed by binary splits, and the data were recursively partitioned into subsets, which was as homogeneous as possible. The splitting procedures would stop when trees reached the specified minimum number of samples allowed at the node. The trees were then pruned by the complexity parameter $(c p)$ at any node, which was the proportion in prediction at each node.

The regression trees were written in the $\mathrm{R}$ programming language and "anova" and "mrt" methods were chosen to construct regression trees. The minimum count of samples (MinS) involved at any node was $5, c p$ at the any end node was 0.01 , the fitness was defined by relative error $(R E)$, and the prediction validity of model was expressed by $1-R E$.

\subsection{Risk assessment of heavy metals accumulation}

Soil accumulation of heavy metals like $\mathrm{Cd}, \mathrm{Cu}, \mathrm{Pb}$ and $\mathrm{Zn}$ would harm the integrity of urban soil ecosystem. Their potential risks are dependent on spatial information of emission sources and topographic conditions (Wang et al., 2012b). To assess the risk of heavy metal accumulation/loss in soils across the urban landscape, we followed the mathematical form of the Universal Soil Loss Equation (USLE) which was original designed to estimate long-term annual erosion rates on agricultural fields by different factors (Wischmeier and Smith, 1978), and developed a cell-by-cell GIS-based overlay model. The model was given as:

$\mathrm{P}=\sum W_{i} \cdot F_{i}$

where $P$ is the soil accumulation risk of specific heavy metal, $F$ is the selected significant influence factors for each heavy metal based on results of the regression trees analysis, and $\mathrm{W}$ is the corresponding weight for each factor.

The data of all selected factors in each cell were standardized before the calculation of the accumulation risk. The weight was the percentage of $1-R E$ for each factor with respect to the total 1-RE. Based on the calculated risks, study area were grouped into low, 
Table 1

Description of influence factors used to construct regression trees.

\begin{tabular}{|c|c|c|}
\hline Category & Influence factor & Description \\
\hline Soil property & $\mathrm{pH}, \mathrm{CLAY}, \mathrm{SOC}, \mathrm{CEC}$ & $\begin{array}{l}\text { The means value of soil } \mathrm{pH} \text {, percentage of clay particle (\%), soil organic carbon (\%), soil } \\
\text { exchange capacity }\left(\mathrm{cmol} \mathrm{kg}^{-1}\right) \text { of soil samples in each cell }\end{array}$ \\
\hline Land use type & RES, PUB, COM, IND, TRA, P\&G, AGR, UNU & $\begin{array}{l}\text { The area percent of different land uses in each cell, include residential, public, commercial, } \\
\text { industrial, traffic, park and greenbelt, agricultural and unused land types }\end{array}$ \\
\hline $\begin{array}{l}\text { Landscape } \\
\text { metrics }\end{array}$ & $\begin{array}{l}\text { AI, ED, NP, PD, LPI, LSI, PAFRAC, SIEI, CONTAG, IJI, PLADJ, } \\
\text { COHESION, PR, DIVISION, MESH, SPLIT, PRD, SHDI, SIDI, SHEI, }\end{array}$ & $\begin{array}{l}\text { aggregation index, edge density, number of patches, patch density, largest patch index, } \\
\text { landscape shape index, perimeter-area fractal dimension, Simpson's evenness index, } \\
\text { contagion, interspersion \& juxtaposition, percentage of like adjacencies, patch cohesion } \\
\text { index, patch richness, landscape division index, effective mesh size, splitting index, patch } \\
\text { richness density, Shannon's diversity index, Simpson's diversity index, Shannon's } \\
\text { evenness index, }\end{array}$ \\
\hline Population & 10POP, PGR & Population density in 2010, annual population growth rate from 2000 to 2010 in each cell \\
\hline $\begin{array}{l}\text { Meteorological } \\
\text { data }\end{array}$ & DIR, SPEED & $\begin{array}{l}\text { The study area gridding was divided into } 8 \text { groups and were expressed by number, N-1, } \\
\text { NE-2, E-3, SE-4, S-5, SW-6, W-7, NW-8. The } 4 \text { years average wind speeds were assigned to } \\
\text { each cell. }\end{array}$ \\
\hline
\end{tabular}

Table 2

Concentration of heavy metals in Beijing at 231 soil sample sites and corresponding background $\left(\mathrm{mg} \mathrm{kg}^{-1}\right)$.

\begin{tabular}{|c|c|c|c|c|}
\hline & $\mathrm{Cd}$ & $\mathrm{Cu}$ & $\mathrm{Pb}$ & $\mathrm{Zn}$ \\
\hline Max & 0.486 & 213.147 & 135.371 & 225.211 \\
\hline Min & 0.066 & 8.408 & 11.178 & 26.711 \\
\hline Mean \pm S.D. & $0.138 \pm 0.058$ & $20.810 \pm 17.45$ & $25.357 \pm 14.565$ & $80.278 \pm 29.485$ \\
\hline C.V. $(\%)$ & 41.823 & 83.874 & 57.442 & 36.729 \\
\hline Background of soils in Beijing ${ }^{a}$ & 0.15 & 19.7 & 25.1 & 59.6 \\
\hline Background of soils in China ${ }^{b}$ & 0.10 & 22.6 & 26.0 & 74.2 \\
\hline
\end{tabular}

a Chen et al., 2004.

b Wei et al., 1991.

middle, and high risk regions by the Quantile method and mapped by spatial analysis in ArcGIS. In this manner, the study region was equally classified into three groups and the regions which have relatively high risk of heavy metal accumulation without reference data were distinguished.

\section{Results and discussion}

\subsection{Spatial distribution of the heavy metal geoaccumulation index}

The heavy metal contents of urban soils in Beijing were spatially heterogeneous (Table 2). The means of $\mathrm{Cd}, \mathrm{Cu}, \mathrm{Pb}$ and $\mathrm{Zn}$ concentrations were $0.138,20.810,25.357$, and $80.278 \mathrm{mg} \mathrm{kg}^{-1}$, respectively and the ranges of $\mathrm{Cd}, \mathrm{Cu}, \mathrm{Pb}$ and $\mathrm{Zn}$ concentrations varied from 0.066 to $0.486,8.408$ to $213.147,11.178$ to 135.371 , and $26.711-225.211 \mathrm{mg} \mathrm{kg}^{-1}$, respectively. Among metals, the soil $\mathrm{Cu}$ showed the highest spatial variations with the coefficient of variation (CV) at $84 \%$, followed by $\mathrm{Pb}, \mathrm{Cd}$, and $\mathrm{Zn}$ with $\mathrm{CV}$ at 57,42 , and $37 \%$, respectively.

In terms of the geo-accumulation index, $I_{\text {geo }}$, heavy metal pollution of the urban soils were at the level 2 (contaminated) or lower (Fig. 2). Area-wise, the soil pollution were primarily at level 0 (uncontaminated) to 1 (moderatelyly contaminated) with soils in most of the area exhibited $\mathrm{I}_{\text {geo }} \leq 0$ or $0 \leq \mathrm{I}_{\text {geo }} \leq 1$ with respect to $\mathrm{Cd}$, $\mathrm{Pb}$, and $\mathrm{Zn}$, while small and isolated parts exhibited $\mathrm{I}_{\text {geo }}>1$. Spatially, $70 \%$ of the study area was deemed uncontaminated and $10 \%$ of the area was contaminated by 2 or more metal elements at the same time. Overall, urban soils of Beijing sustained low levels of $\mathrm{Cd}, \mathrm{Cu}, \mathrm{Pb}$, and $\mathrm{Zn}$ pollution, while $\mathrm{Zn}$ pollution was area-wise the most extensive and $\mathrm{Cu}$ pollution was concentration-wise the most severe.

\subsection{Regression trees establishment}

Both the un-pruned univariate and multivariate regression trees showed good prediction as the 1-RE were greater than 0.6 (Table 3 ). However, the resulting trees involved 23 to 29 TNs, and Tvars, were 9-12 that making the outcomes more complicated to interpret. After pruning the redundant nodes based on the complexity parameter (cp), the total nodes, TN, in the pruned tree were reduced to 17 to 23 and total variable count, Tvar, were reduced to 6 to 8 . The total nodes were reduced by $4,8,10,4$, and 6 and total count of variables, Tvar, were reduced by 3, 2, 4, 2, and 2 for $\mathrm{Cd}, \mathrm{Cu}$, $\mathrm{Pb}, \mathrm{Zn}$, and MRT, respectively. The 1-RE of pruned regression trees were $0.652,0.590,0.677$, and 0.675 for $\mathrm{Cd}, \mathrm{Cu}, \mathrm{Pb}$, and $\mathrm{Zn}$ trees, respectively and was 0.662 for the multivariate tree. The pruned regression trees were selected for the further evaluations, as they were smaller and less complicated than the un-pruned ones in terms of analyses yet were equal in terms of predicting the outcomes.

\subsection{Relationships between heavy metals and influence factors}

The regression trees illustrated the relationships between the soils' heavy metals content (dependent variables) and the influence factors (independent variables) including variables representing soil properties, land use type, landscape metrics, population, and meteorological data (Figures $1 \mathrm{~S}$ and $2 \mathrm{~S}$ ). The more an independent variable showed up in the tree, the closer was its relationship to the corresponding dependent variable (White et al., 2005).

The primary factors influencing the accumulations in soils were metal specific. For Cd, the factors included soil organic carbon (SOC, $1-\mathrm{RE}=0.313$ ), annual growth rate of population (PGR, 1$\mathrm{RE}=0.152$ ), wind speed ( $\mathrm{SPD}, 1-\mathrm{RE}=0.053)$, landscape patterns (IJI, 1-RE $=0.085$ and PAFRAC, $1-\mathrm{RE}=0.030$ ), and the area of commercial land use (COM, $1-\mathrm{RE}=0.019)$. For $\mathrm{Cu}$, the factors were soil's cation exchange capacity (CEC, $1-\mathrm{RE}=0.206)$, population growth $(\mathrm{PGR}, 1-\mathrm{RE}=0.068)$, landscape patterns $(\mathrm{SHDI}, 1-\mathrm{RE}=0.131$ and LSI, $1-R E=0.075)$, areas of public and commercial land use (PUB, 1-RE $=0.065$ and RES, 1-RE $=0.02$ ), and wind speed (SPE, 1- 
Cd

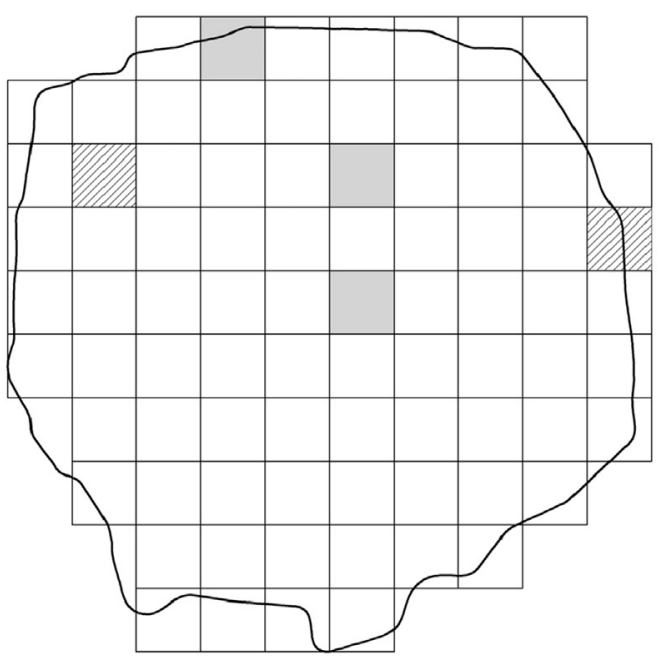

$\mathrm{Pb}$

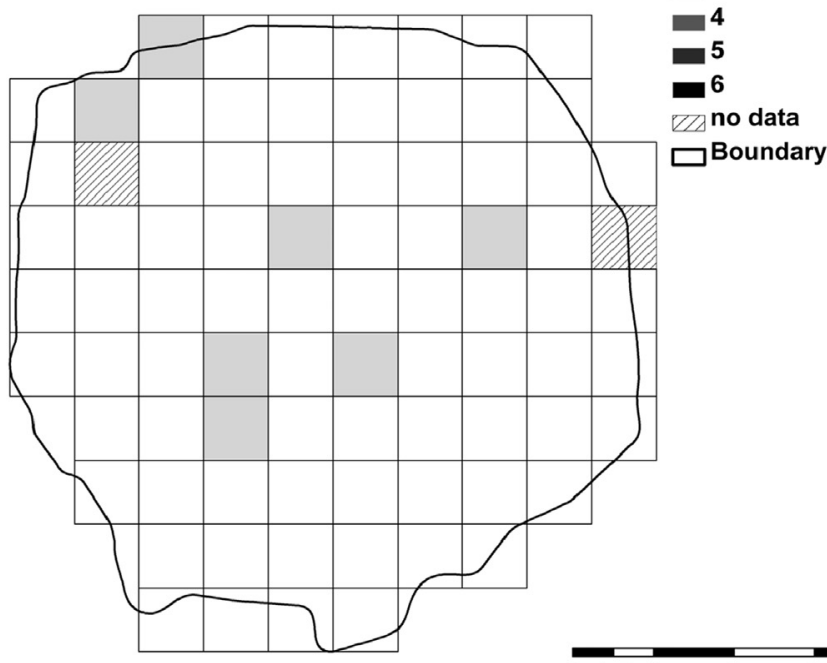

$0 \longdiv { 1 . 5 3 }$
$\mathrm{N}$

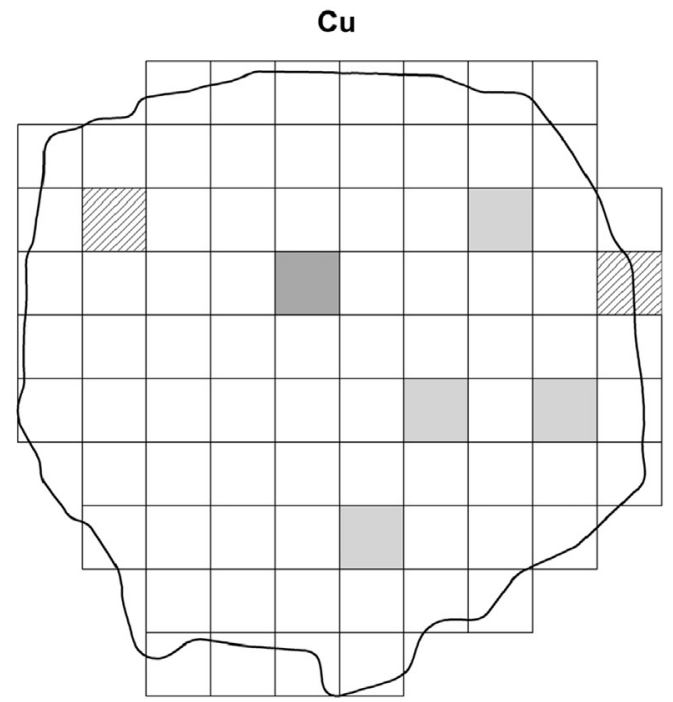

$\mathrm{Zn}$

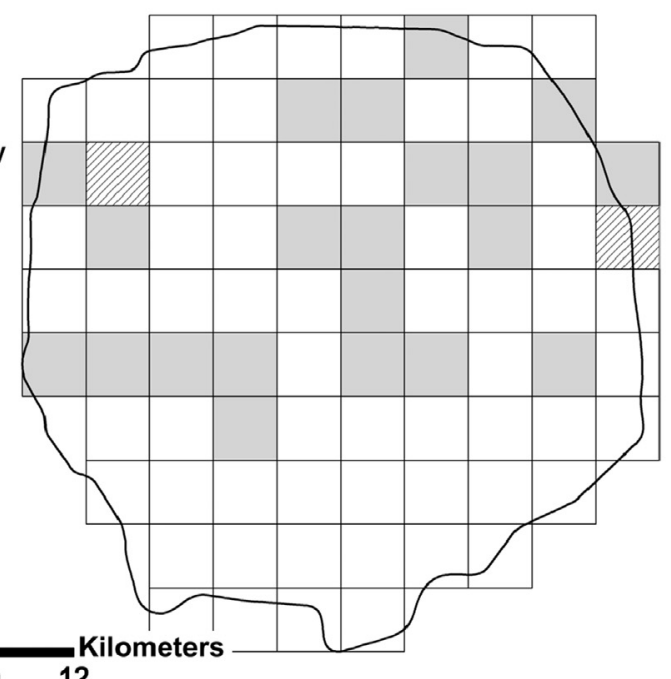

Fig. 2. Spatial distributions of $\mathrm{I}_{\text {geo }}$ of heavy metal $\mathrm{Cd}, \mathrm{Cu}, \mathrm{Pb}$ and $\mathrm{Zn}$.

Table 3

Comparison of un-pruned and pruned regression trees.

\begin{tabular}{|c|c|c|c|c|c|c|c|c|c|}
\hline \multirow[t]{2}{*}{ Trees } & \multicolumn{3}{|c|}{ Un-pruned } & \multicolumn{6}{|c|}{ Pruned } \\
\hline & $\mathrm{TN}$ & MinS & $1-\mathrm{RE}$ & Tvar & $\mathrm{TN}$ & MinS & 1-RE & Tvar & $\mathrm{cp}$ \\
\hline $\mathrm{Cd}$ & 23 & 5 & 0.668 & 9 & 17 & 5 & 0.652 & 6 & 0.01 \\
\hline $\mathrm{Cu}$ & 25 & 5 & 0.620 & 9 & 17 & 5 & 0.590 & 7 & 0.01 \\
\hline $\mathrm{Pb}$ & 29 & 5 & 0.696 & 12 & 19 & 5 & 0.677 & 8 & 0.01 \\
\hline $\mathrm{Zn}$ & 27 & 5 & 0.703 & 11 & 23 & 5 & 0.685 & 9 & 0.01 \\
\hline MRT & 27 & 5 & 0.692 & 10 & 21 & 5 & 0.662 & 8 & 0.01 \\
\hline
\end{tabular}

Note: TN means the total nodes of regression tree; MinS means the minimum count of samples (MinS) involved at any node; $R E$ means relative error, and the prediction validity of model was expressed by $1-R E$; Tvar means total variable count for a tree; $c p$ means complexity parameter for total nodes.

$\mathrm{RE}=0.025$ ). Factors influencing the $\mathrm{Pb}$ and $\mathrm{Zn}$ in the soils might be teased out in the same manners. Undoubtedly, the sources of emission were not the same for each metal and once emitted their fate and transport were affected by multitude of factors including the soil properties and land use patterns. For four heavy metals $(\mathrm{Cd}$, $\mathrm{Cu}, \mathrm{Pb}, \mathrm{Zn}$ ) combined, the accumulations were influenced by the soil's organic carbon (SOC, $1-\mathrm{RE}=0.301$ ) and cation exchange capacity (CEC, 1-RE = 0.071), population growth (PGR, 1$\mathrm{RE}=0.045)$, landscape patterns (NP, 1-RE $=0.072$, PRD, 1$\mathrm{RE}=0.011$, and SHDI, $1-\mathrm{RE}=0.054$ ), and areas of traffic and public land use (TRA, 1-RE $=0.016$ and PUB, $1-\mathrm{RE}=0.090$ ). The soil's organic carbon and cation exchange capacity were the key soil attributes governing the resulting chemical forms of the deposits and the metal sorption capacities of urban soils (Davis, 1984; Zeng et al., 2011). The soil's pH (changed from 7.44 to 8.90, with coefficient of variation at $3.217 \%$ ) and clay content (changed from $2.512 \%$ to $17.669 \%$, with coefficient of variation at $35.608 \%$ ) showed rather small spatial variations and they did not exhibit any significant contribution to the heavy metal accumulation in regression trees of Cd, Cu, Pb, Zn and MRT (Vega et al., 2004; Obrador et al., 2007).

Anthropogenic activities also significantly impact the accumulation of heavy metal in urban soils (Tessier et al., 1979). In the resulting regression trees, land uses including residential, commercial, public, traffic and industrial as well as demographics including population density and growth were closely significantly related to accumulation patterns.

The urban landscape as a result of human activities was defined more in terms of regularity and shape and less by the land uses and fragmented small-scale patches and the urban landscape might be 
Table 4

Relative importance of influence factors in the constructed regression tree.

\begin{tabular}{|c|c|c|c|c|c|c|c|c|c|}
\hline \multicolumn{2}{|l|}{$\mathrm{Cd}$} & \multicolumn{2}{|l|}{$\mathrm{Cu}$} & \multicolumn{2}{|l|}{$\mathrm{Pb}$} & \multicolumn{2}{|l|}{$\mathrm{Zn}$} & \multicolumn{2}{|c|}{ Comprehensive } \\
\hline Factor & Weigh & Factor & Weigh & Factor & Weigh & Factor & Weigh & Factor & Weigh \\
\hline SOC & 0.480 & CEC & 0.349 & SOC & 0.511 & SOC & 0.363 & SOC & 0.456 \\
\hline PGR & -0.233 & SHDI & -0.222 & PAFRAC & 0.155 & PGR & -0.210 & CEC & 0.108 \\
\hline IJI & 0.130 & LSI & 0.127 & IND & -0.116 & PUB & 0.163 & NP & 0.109 \\
\hline SPEED & -0.081 & PGR & -0.115 & RES & -0.084 & CEC & 0.107 & PGR & -0.068 \\
\hline PAFRAC & -0.046 & PUB & -0.110 & PGR & -0.059 & NP & 0.090 & TRA & -0.024 \\
\hline \multirow[t]{4}{*}{$\mathrm{COM}$} & 0.029 & RES & -0.033 & TRA & -0.032 & $10 \mathrm{POP}$ & 0.018 & PUB & 0.136 \\
\hline & & SPEED & 0.042 & PUB & -0.022 & TRA & -0.028 & PRD & 0.017 \\
\hline & & & & LPI & 0.019 & PRD & 0.018 & SHDI & 0.082 \\
\hline & & & & & & COM & 0.018 & & \\
\hline
\end{tabular}

characterized in various manners. The metrics such as perimeterarea fractal dimension (PAFRAC), metric and landscape shape index (LSI) reflected the characteristics of urban shapes. The largest patch index (LPI) and number of patches (NP) were metrics indicating the fragmentation of urban landscape. The Shannon's diversity index (SHDI) and patch richness density (PRD) described the diversity of land uses. Interspersion and juxtaposition (IJI) indicated the contagion of the land uses. They were included in the regression tree analyses and IJI and PAFRAC were significant factors on Cd and SHDI and LSI were significant factors on $\mathrm{Cu}$ accumulations in urban soils. The spatial distribution (IJI) and shape (PAFRAC, LSI) of land use would influence the traffic condition, while the land use type diversity would link with the degree of urban development and intension of human activities, therefore, landscape metrics could be significant factors for some heavy metals accumulation.

The microclimatic factors would influence atmospheric fallouts and distributions of the emitted heavy metals in urban soils (McGrath et al., 2004; Juang et al., 2001; Lado et al., 2008). The speed and direction of wind were important factors in spreading and distributing airborne pollutants (Wu et al., 2008; Chen et al., 2010; Nezhad et al., 2015). According to the regression trees (Figure 1S), the wind speed (SPE) exhibited pronounced effects on $\mathrm{Cd}$ and $\mathrm{Cu}$ accumulations in urban soils.

The factors exerted different influences either accelerating or slowing down the heavy metal accumulation processes in the urban soil (Figures $1 \mathrm{~S}$ and $2 \mathrm{~S}$ ) and each factor exhibited a different

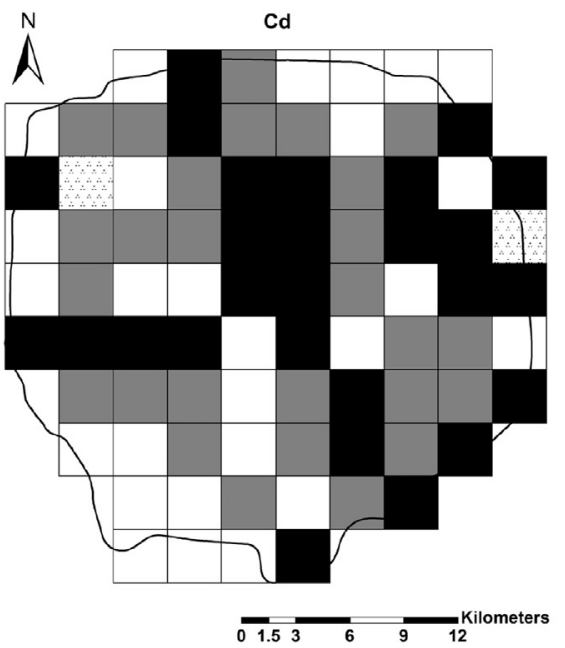

$\mathrm{Pb}$

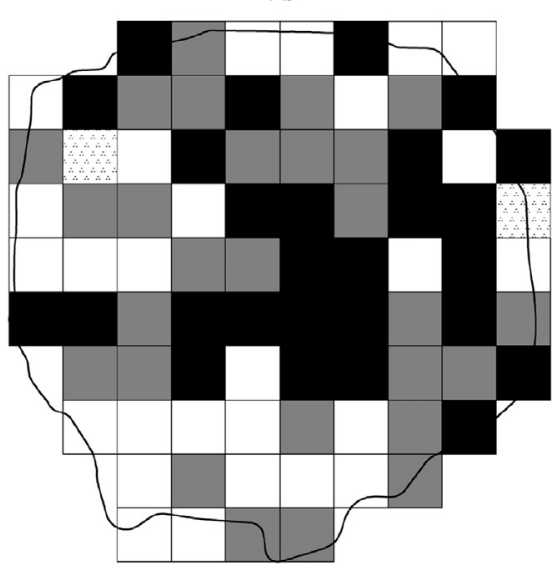

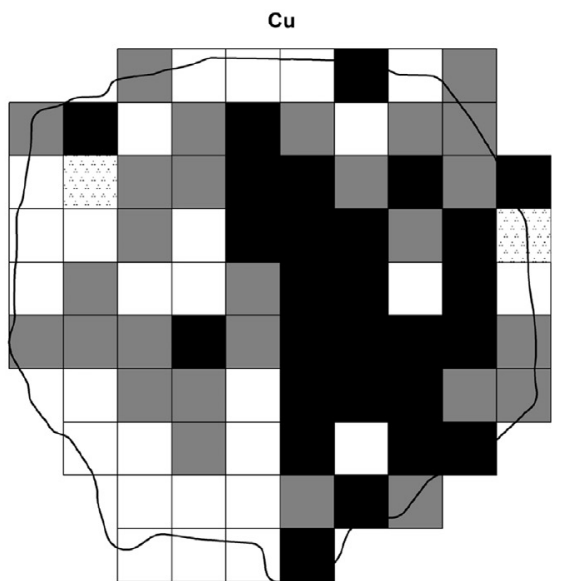

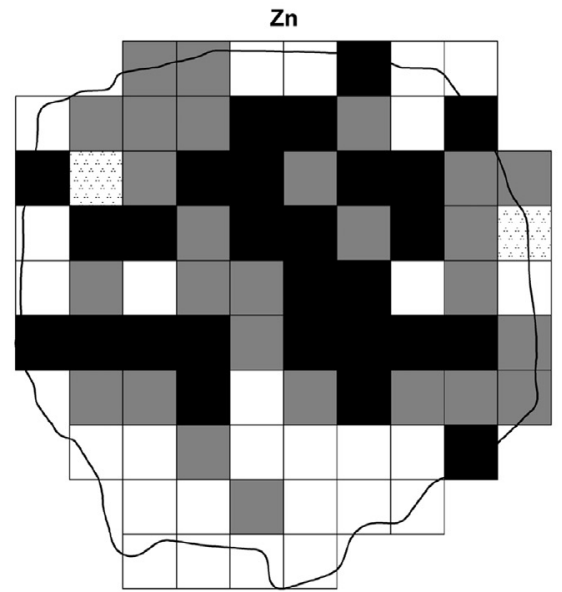

Fig. 3. Spatial distributions of accumulation risks.

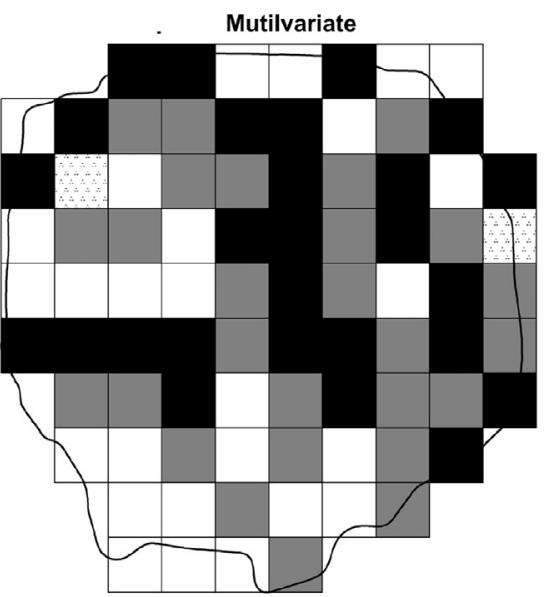

Accumulation Risk

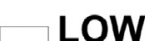

MIDDLE

HIGH

Boundary

No Data 
cause - effect context. For examples, soil properties such as the organic carbon and cation exchange capacity exerted positive impacts to increase the heavy metal accumulation due to their abilities to chemically immobilize metals in the soils (Davis, 1984). The population growth (PGR) exerted negative influences yet the population density (10POP) exerted positive influences on the accumulations. The areas of high population density logically exhibited lower rate of population growth. Because of higher population per unit area, the pollutant emissions of the higher population area would be proportionally increased therefore higher metal accumulations in the surrounding soils. Wind speed negative influenced the $\mathrm{Cd}$ and positive influenced the $\mathrm{Cu}$ accumulations in urban soils as $\mathrm{Cd}$ was emitted primarily by the mobile sources of vehicular traffic thus susceptible to atmospheric transport while the $\mathrm{Cu}$ was emitted primarily from stationary industrial production sources thus tended to staying local (Wang et al., 2012b). All of the land use related factors involved in the regression trees (i.e. RES, PUB, IND and TRA) showed negative impacts while all landscape pattern related factors involved in regression trees (i.e. PAFRAC, SHDI, LSI, LPI, NP, PRD and IJI) showed positive influences on the heavy metal accumulation in the urban soils. Unlike the previously identified physical factors, we were unable to fully comprehend the complicated interrelations between these descriptive parameters and the heavy metal accumulations in urban soils (Table 4 ).

\subsection{Assessment of heavy metals accumulation risks}

The heavy metal accumulation risks of urban soils could be evaluated based on outcomes of the regression trees and Eq. (2). For Beijing, the risks varied from low to high and the spatial patterns of risks were similar among $\mathrm{Cd}, \mathrm{Cu}, \mathrm{Pb}$, and $\mathrm{Zn}$. The regions with areas of high risks were concentrated at the central-east and west sections and the areas of low risks were concentrated at the south sections of the city (Fig. 3).

For $\mathrm{Cd}$ and $\mathrm{Cu}$, high risk regions were more concentrated at eastcentral, while for $\mathrm{Pb}$ and $\mathrm{Zn}$, high risk regions were more concentrated at north-central. Comparing with single heavy metal accumulation risks, the distribution of multiple accumulation risk for 4 heavy metals was more decentralized. High risk regions were generally distributed in the north margin, east-central and parts of west, while most low risk regions were distributed in south and north-west.

Judging by the spatial distributions of accumulation risks of individual metals, the accumulations were related to the extent of urbanization, high risks regions were associated with high level of urbanization. For four metals combined accumulation risks, in addition to high degree of urbanization, the regions were surrounded with intense vehicular traffics. Intensive human activities were key factors affecting heavy metals $(\mathrm{Cd}, \mathrm{Cu}, \mathrm{Pb}$ and $\mathrm{Zn})$ accumulation in urban soils of Beijing.

\section{Conclusions}

We divided the metropolitan Beijing into north-south and eastwest grids with 81 cells. The $\mathrm{Cd}, \mathrm{Cu}, \mathrm{Pb}$ and $\mathrm{Zn}$ contents of soils in each cell along with metrics characterizing the soil properties, land use pattern, demographics, and microclimatic conditions were determined. The $\mathrm{Cd}, \mathrm{Cu}, \mathrm{Pb}$ and $\mathrm{Zn}$ distributions in urban soils were spatially heterogeneous with coefficients of variation (CV) of 42,84 , 57 , and $37 \%$, respectively. The soils, based on the geo-accumulation indices, were characterized as slightly polluted in terms of $\mathrm{Cd}, \mathrm{Cu}$, $\mathrm{Pb}$ and $\mathrm{Zn}$ accumulations in the soils. Zinc accumulations were the most extensive and $\mathrm{Cu}$ accumulations were the most acute.

The regression tree analyses showed that the accumulations of $\mathrm{Cd}, \mathrm{Cu}, \mathrm{Pb}$ and $\mathrm{Zn}$ in urban soils were caused by different sets of influence factors, suggesting that their emission sources and environmental behaviors of each metal were unique. By far, the soil organic carbon was the most prominent factor affecting the accumulations regardless of the element and it was followed by population growth and the cation exchange capacity. Influence of wind speed on accumulation of $\mathrm{Cd}$ and $\mathrm{Cu}$ was significant. The metrics characterizing the land use pattern also showed significant influences on heavy metal accumulations. The relationships however were complicate and difficult to quantify.

The areas of high heavy metal accumulation risks were associated with high degrees of urbanization and were surrounded with intense vehicular traffics.

\section{Acknowledgements}

We acknowledge the financial support of the National Natural Science Foundation of China (\#41173123).

\section{Appendix A. Supplementary data}

Supplementary data related to this article can be found at http:// dx.doi.org/10.1016/j.envpol.2015.11.044.

\section{References}

Bermea, O.M., Álvarez, E.H., Hernández, G.G., Romero, F., Lozano, R., Orosco, L.E.B., 2009. Assessment of heavy metal pollution in urban topsoils from the metropolitan area of Mexico City. J. Geochem. Explor. 101 (3), 218-224.

Breiman, L., 2001. Decision-tree forests. Mach. Learn. 45 (1), 5-32.

Chabukdhara, M., Nema, A.K., 2013. Heavy metals assessment in urban soil around industrial clusters in Ghaziabad, India: Probabilistic health risk approach. Ecotoxicol. Environ. Saf. 87 (1), 57-64.

Chen, T.B., Zheng, Y.M., Chen, H., Zheng, G.D., 2004. Background concentrations of soil heavy metals in Beijing. Environ. Sci. 25 (1), 117-122.

Chen, X., Xia, X.H., Zhao, Y., Zhang, P., 2010. Heavy metal concentrations in roadside soils and correlation with urban traffic in Beijing, China. J. Hazard. Mater. 181 (1-3), 640-646.

Davis, J.A., 1984. Complexation of trace metals by absorbed natural organic matter Geochimica Cosmochimica Acta 48, 679-691.

Desmet, P.J.J., Govers, G., 1996. A GIS procedure for automatically calculating the USLE LS factor on topographically complex landscape units. J. soil water conservation $51,427-433$.

Goovaerts, P., 2000. Estimation or simulation of soil properties? an optimization problem with conflicting criteria. Geoderma 97, 165-186.

Greve, M.H., Kheir, R.B., Greve, M.B., Bøcher, P.K., 2012. Quantifying the ability of environmental parameters to predict soil texture fractions using regressiontree model with GIS and LIDAR data: the case study of Denmark. Ecol. Indic. $18,1-10$.

Han, Y., Du, P., Cao, J., Eric, S., 2006. Multivariate analysis of heavy metal contamination in urban dusts of Xi'an, Central China. Sci. Total Environ. 355, 176-186.

Henderson, B.L., Bui, E.N., Moran, C.J., Simon, D.A.P., 2005. Australia-wide predictions of soil parameters using decision trees. Geoderma 124, 383-398.

Journel, A., Kyriakidis, P., Mao, S., 2000. Correcting the smoothing effect of estimators: a spectral postprocessor. Math. Geol. 32, 787-813.

Juang, K.W., Lee, D.Y., Ellsworth, T.R., 2001. Using rank-order geostatistics for spatial interpolation of highly skewed data in a heavy-metal contaminated site. J. Environ. Qual. 30 (3), 894-903.

Kheir, R.B., Shomar, B., Greve, M.B., Greve, M.H., 2014. On the quantitative relationships between environmental parameters and heavy metals pollution in Mediterranean soils using GIS regression-trees: the case study of Lebanon. J. Geochem. Explor. 147, 250-259.

Lado, L.R., Hengl, T., Reuter, H.I., 2008. Heavy metals in European soils: a geostatistical analysis of the FOREGS geochemical database. Geoderma 148 (2), 189-199.

Legret, M., Pagotto, C., 2006. Heavy metal deposition and soil pollution along two major rural highways. Environ. Technol. 27 (3), 247-254.

Lin, Y.P., Teng, T.P., Chang, T.K., 2002. Multivariate analysis of soil heavy metal pollution and landscape pattern in Changhua County in Taiwan. Landsc. Urban Plan. 62, 19-35.

McGrath, D., Zhang, C.S., Carton, O.T., 2004. Geostatistical analyses and hazard assessment on soil lead in Silvermines area. Irel. Environ. Pollut. 127 (2), 239-248.

Mmolowa, K.B., Likuku, A.S., Gaboutloeloe, G.K., 2011. Assessment of heavy metal pollution in soils along major roadside areas in Botswana, African. J. Environ. Sci. Technol. 5 (3), 186-196.

Nezhad, M.T.K., Tabtabaii, S.M., Gholami, A., 2015. Geochemical assessment of steel smelter-impacted urban soils, Ahvaz, Iran. J. Geochem. Explor. 152, 91-109. 
Obrador, A., Alvarez, J.M., Lopez-Valdivia, L.M., Gonzalez, D., Novillo, J., Rico, M.I. 2007. Relationships of soil properties with Mn and $\mathrm{Zn}$ distribution in acidic soils and their uptake by a barley crop. Geoderma 137, 432-443.

Palumbo, B., Angelone, M., Bellanca, A., Dazzi, C., Hauser, S., Neri, R., Wilson, J., 2000 Influence of inheritance and pedogenesis on heavy metal distribution in soils of Sicily, Italy. Geoderma 95 (3-4), 247-266.

Pouyat, R.V., McDonnell, M.J., 1991. Heavy metal accumulations in forest soils along an urban-rural gradient in southeastern New York. USA. Water Air Soil Pollut. 57 (8), 797-807.

Razi, M.A., Athappilly, K., 2005. A comparative predictive analysis of neural networks (NNs), nonlinear regression and classification and regression tree (CART models. Expert Syst. Appl. 29 (1), 65-74.

Tessier, A., Campbell, P.G.C., Bisson, M., 1979. Sequential extraction procedure for the speciation of particulate trace metals. J. Anal. Chem. 51 (7), 844-851.

Vega, F.A., Covelo, E.F., Andrade, M.L., Marcet, P., 2004. Relationships between heavy metals content and soil properties in minesoils. Anal. Chim. Acta 524, 141-150.

Wang, M.E., Markert, B., Chen, W.P., Peng, C., Ouyang, Z.Y., 2012a. Identification of heavy metal pollutants using multivariate analysis and effects of land uses on their accumulation in urban soils in Beijing, China. Environ. Monit. Assess. 184 (10), 5889-5897.

Wang, M.E., Bai, Y.Y., Chen, W.P., Markert, B., Peng, C., Ouyang, Z.Y., 2012b. A GIS technology based potential eco-risk assessment of metals in urban soils in Beijing, China. Environ. Pollut. 161, 235-242.

Wei, B.G., Yang, L.S., 2010. A review of heavy metal contaminations in urban soils, urban road dusts and agricultural soils from China. Microchem. J. 94, 99-107.

Wei, F.S., Chen, J.S., Wu, Y.Y., Zheng, C.J., 1991. Background concentrations of elements in soils of China. Water, Air, Soil Pollut. 57-58, 699-712.

White, A.B., Kumar, P., Tcheng, D.A., 2005. A data mining approach for understanding topographic control on climate induced inter-annual vegetation variability over the United States. Remote Sens. Environ. 98, 1-20.

Wischmeier, W.H., Smith, D.D., 1978. Agricultural Handbook No. 537, United States Department of Agriculture. springfield, USA.

WRB, 2006. World Reference Based for Soil Resources 2006. IUSS Working Group WRB. World Soil Resources Report, No. 103, Rome.

Wu, Z.J., Hu, M., Lin, P., Liu, S., Wehner, B., Wiedensohler, A., 2008. Particle Number Size Distribution in the Urban Atmosphere of Beijing, China.

Xia, X.H., Chen, X., Liu, R.M., Liu, H., 2011. Heavy metals in urban soils with various types of land use in Beijing, China. J. Hazard. Mater. 186 (2-3), 2043-2050.

Zeng, F.R., Ali, S., Zhang, H.T., Ouyang, Y.N., Qiu, B.Y., Wu, F.B., Zhang, G.P., 2011. The influence of $\mathrm{pH}$ and organic matter content in paddy soil on heavy metal availability and their uptake by rice plants. Environ. Pollut. 159 (1), 84-91. 